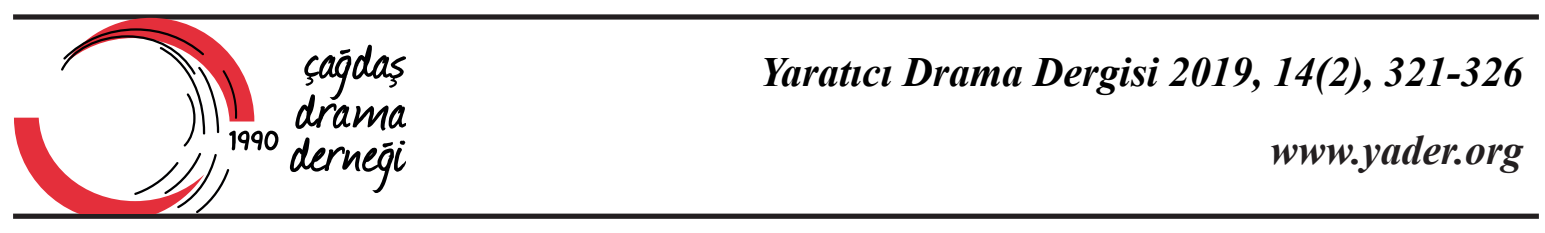

\title{
Working in Role: Teachers and Children
}

\section{Patrice Baldwin ${ }^{1}$}

\begin{tabular}{|c|c|}
\hline Article Info & Abstract \\
\hline DOI: $10.21612 /$ yader.2019.019 & $\begin{array}{l}\text { Drama as a learning medium, has its roots in dramatic play. Very young babies naturally } \\
\text { imitate and mimic what they see and hear. Once they are able to move around, toddlers }\end{array}$ \\
\hline Article History & start trying out things that they have seen adults doing. For example, they might \\
\hline Received & pretend to cook, make imaginary cups of tea, drive imaginary cars and motorbikes, \\
\hline 24.05 .2019 & $\begin{array}{l}\text { pretend they are talking to someone on a mobile phone, etc. They sometimes use } \\
\text { functional toys in their dramatic play, e.g. a toy teapot 'as if' it were a real teapot, } \\
\text { but they also use ambiguous obiects imaginativelv 'as if' thev are something else. }\end{array}$ \\
\hline Keywords & For example, a cardboard box might become a car, a stick might become a knife. \\
\hline Working in role & They often bring in dolls, furry toys, their pets or imaginary friends into their role- \\
\hline Teacher in role & play scenarios, as the other characters. Children will also role-play together and \\
\hline Teacher & sometimes with adults. The role play is not real but the skills being developed are \\
\hline Children & $\begin{array}{l}\text { real, e.g. co-operation, collaboration, turn taking, negotiation, listening, fine motor } \\
\text { skills, etc. Whilst imitating, mimicking and improvising, they are using real language } \\
\text { purposefully, within a range of familiar or newly imagined contexts. They feel confident }\end{array}$ \\
\hline Article Type & and successful in their make believe worlds and are often rehearsing adult situations \\
\hline The Letter of Opinion & $\begin{array}{l}\text { and activities. Young children in schools get time in role play areas (both indoors and } \\
\text { outdoors). They sometimes have teachers and/or other adults interacting with them } \\
\text { as they role play but they also should have opportunity for their own, free role play } \\
\text { without adults involved. A teacher (or other adult), role-playing with children can } \\
\text { help focus and maintain children's attention, model various types of talk, give status } \\
\text { to their make believe and introduce problems to be resolved together. Teachers in role } \\
\text { can stimulate and challenge the children's various types of thinking and inter-thinking, } \\
\text { from within an engaging and compelling fiction }\end{array}$ \\
\hline
\end{tabular}

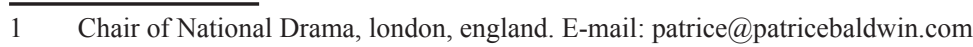




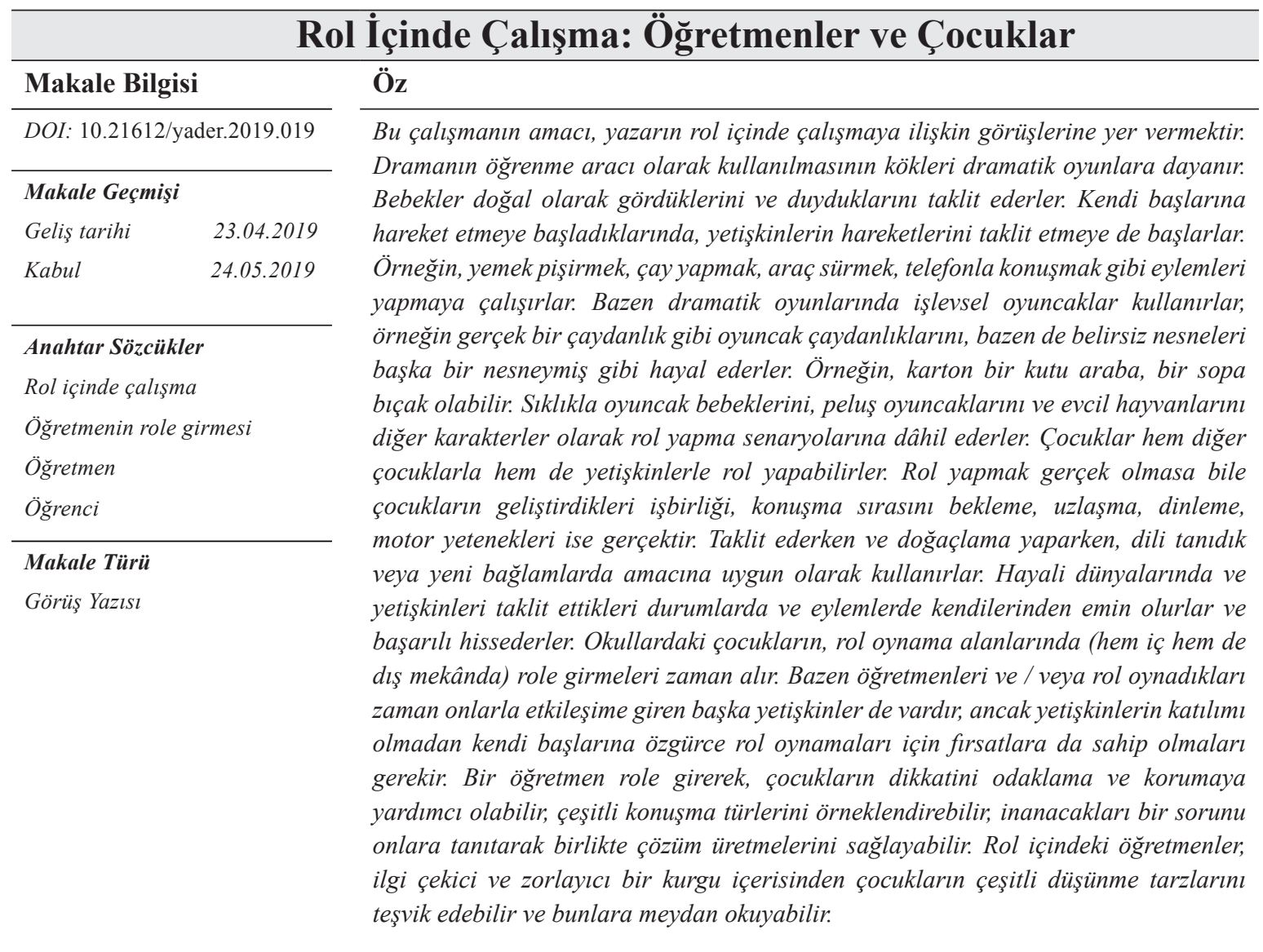


Drama as a learning medium, has its roots in dramatic play. Very young babies naturally imitate and mimic what they see and hear. Once they are able to move around, toddlers start trying out things that they have seen adults doing. For example, they might pretend to cook, make imaginary cups of tea, drive imaginary cars and motorbikes, pretend they are talking to someone on a mobile phone, etc. They sometimes use functional toys in their dramatic play, e.g. a toy teapot 'as if' it were a real teapot, but they also use ambiguous objects imaginatively, 'as if' they are something else. For example, a cardboard box might become a car, a stick might become a knife. They often bring in dolls, furry toys, their pets or imaginary friends into their role-play scenarios, as the other characters. Children will also role-play together and sometimes with adults. The role play is not real but the skills being developed are real, e.g. co-operation, collaboration, turn taking, negotiation, listening, fine motor skills, etc. Whilst imitating, mimicking and improvising, they are using real language purposefully, within a range of familiar or newly imagined contexts. They feel confident and successful in their make believe worlds and are often rehearsing adult situations and activities.

Parents, teachers and teaching assistants sometimes choose to join in children's dramatic role-play. They are hopefully alert to the many learning opportunities that arise, and to ways they can raise the level of challenge from within the shared, imagined scenario. Adults may choose to deliberately plant learning opportunities. For example, an adult might enter the child's pretend café as a customer and eat a pretend meal, but then announce that their purse has gone missing and they can't pay for the meal? How will the child in role as a café owner, deal with this unexpected situation? The scenario in the café is not real but it feels as if it is and the situation requires and rehearses real problem solving skills.

Young children in schools get time in role play areas (both indoors and outdoors). They sometimes have teachers and/or other adults interacting with them as they role play but they also should have opportunity for their own, free role play without adults involved. The theme of the role play area in a classroom will be changed from time to time. Often the children help set up the role play area and bring items in for it (sharing ownership of it). For a few weeks it might be a travel agents, with brochures of unfamiliar places. The teacher might enter as a customer who has not decided where to go on holiday. The child presents some possibilities and answers the customer's questions. Next the role play area might become a hospital with bottles, bandages, stethoscopes etc. and the adult might become a new nurse on her first day, who needs training.

Adults should not take over children's self-initiated role - play. They should initially observe and listen to the children interacting in role. It will reveal much about various children's personal, social, emotional and language development, as well as indicate where their interests lie and reveal something of their real life experiences. A teacher (or other adult), role-playing with children can help focus and maintain children's attention, model various types of talk, give status to their make believe and introduce problems to be resolved together. Teachers in role can stimulate and challenge the children's various types of thinking and inter-thinking, from within an engaging and compelling fiction.

\section{Moving from Dramatic Role-play to Whole Class Drama}

An adult as co-participant in dramatic play, can pave the way for using 'teacher in role' in schools. Teachers in role, interacting within a whole class Drama, can be effective at any age. 
Dramatic play, Drama for Learning, Process Drama and Theatre all involve pretending 'in role' together.

It is perfectly possible for teachers to do drama lessons with children and yet never go into role themselves but I would encourage all teachers to have a go at 'Teacher in Role'. Interacting with a teacher in role, is very engaging for children and any associated learning becomes emotionally tagged and highly memorable.

Teachers without drama training, may be understandably nervous about trying 'Teacher in Role' with whole classes but hopefully the following tips and 'rules' will increase their confidence and help them get started. When class teachers see how compelling working in role with children can be, they are likely to add it to their teaching repertoire for any age group.

\section{'Teacher in Role' (Some Tips and Guidelines)}

1) Make sure the children know in advance, that you are going to be a 'Teacher in Role'

Don't just start behaving differently and expect them to guess you are in role. Tell them just before, that you will be going into role. You might start by just being in role for a minute or two. You can always step out of role, talk to them again as their teacher, and then go back into role again. However you must ....

\section{2) Always make it clear to the children, when you are in or out of role}

It might be helpful to 'sign' the role in some way, maybe wearing a simple piece of costume or prop, e.g. 'When I am carrying this notepad, I am the reporter. When I put it down again, I am no longer the reporter.' Or, you could simply say that you will walk away from them and that when you turn around and come back again, you will be a reporter.

\section{3) Maintain seriousness and commitment, whilst you are in role}

You need to maintain the role, with confidence and commitment. Try not to communicate any nervousness or embarrassment. You need the children to work with you in role seriously and confidently, so you need to model that. If you show nervousness or are half-heartedly in role, then the children might feel a bit uncomfortable about interacting with you in role.

\section{4) Decide the main purpose of your 'teacher in role'?}

You need to know why you are taking on a role at any particular point in the drama and what you want to achieve with the role, in terms of the children's thinking and learning. Before you take on a role, you should have the purpose and function of the role clearly in your mind and keep it in mind.

\section{5) What are the main types of role that you might choose from?}

You can define roles in various ways. For example, they can be defined in terms of their status and/or purpose. Most roles are a combination of types, e.g. you could take on a low status information gathering role, or a high status, information giving role, etc.

High Status roles: Teachers who are not used to working in role, sometimes opt too often for 'high status' roles, which helps the teacher to feel secure and in control of children's behaviour. Over use of high status 'teacher in role', is not particularly enabling for the children. If they are usually obeying a teacher in role and following instructions, then this is quite limiting. The teacher needs to 
be an enabler, catalyst, mediator and facilitator of drama as a learning experience not just a director, with the children as their puppets.

You can challenge high status role stereotypes by taking on apparently high status role but in a way that lowers the status and surprises, e.g. you might take on the role of a King but confide in the children (your most trusted servants), that you don't really like being a King and are having nightmares about a hostile neighbouring King. You are frightened and tired and need their advice and help. Now the king's strong and faithful servants are empowered to make suggestions to their weak king, diplomatically.

A high status 'Teacher in role', can be used provocatively to stir up the children in role. The teacher in role can then withdraw for a while, to give the children the opportunity to speak freely about the protagonist. For example, in a drama about two countries (rich and poor), the rich King (teacher in role) can be rude to the poor arrivals, seeking food and shelter (the children in role) and then walk away.

Low status roles: Children will usually rise to the occasion, when they see that someone in role (especially the teacher), needs their help. If you give children roles with assumed knowledge and responsibility, the children will start to feel empowered and will usually rise to the occasion. Mantle of the Expert (which comes under the umbrella of Drama for Learning) is built around this.

I was once a 'teacher in a role' as a low status troll. My job was to stop goats from crossing a bridge to eat the grass. The grass had rare flowers in it. I was not managing to stop the goats, as they were hungry and ignored me. A group of children were in role as my employers. They told me that I was no good at my job and they sacked me! I explained that I really needed the job. I had a family to feed and rent to pay. They had not expected me to prick their consciences in this way and make sacking me more difficult for them. They told me that I could get another job. I explained that I could not read or write. I only knew about flowers. I asked them if they could find a different job for me? They discussed this and decided that I could have a flower stall outside a school. I could sell my flowers and they would ask the school to teach me to read and write, so that I could then apply for other jobs in the future. In drama, the children may have high status roles and make decisions but the teacher needs to then ensure, that they consider the consequences of their decisions.

Intermediary roles: An example of an intermediary role, would be a teacher in role as a messenger from a higher authority. For example, the people who live in Hamelin are plagued by rats. The children are in role as the people who live in Hamelin. The teacher in role as the messenger, has been sent by the Mayor to listen to their complaints. The messenger can listen sympathetically to the people. The messenger has no power. He is just doing his job, gathering information for the Mayor. Rational discussion is more likely to happen, if the townsfolk are talking with a sympathetic intermediary.

Of course the Mayor's messenger could be played differently. He might be the intermediary who takes back the people's messages to the Mayor but is very detached or unsympathetic.

Equal status roles: You can be in the same role as the childrenFor example, you could be just a citizen of Hamelin. You are all deciding together, what to do about the rats and the Mayor. From an equal status position, you can still gather or give information. You can still be compliant or provocative, as different villagers will have different personalities and may have different opinions and viewpoints. 
Information giving roles: A main function of 'teacher in role' is often, to add more information to the Drama. In a drama lesson based on historically true events, i.e. the evacuation of children from London during World War 2, the teacher could take on the role of a government official, giving out copies of the government information leaflets and explaining why parents should send their children to the countryside. Real historical information is being imparted to children by the teacher in role.

Teachers might also decide to take on information giving roles in an entirely fictitious drama, e.g. the teacher is in role as the captain of a Spaceship on a secret mission. The captain tells the children that they are all experts in various fields. They have been invited to be members of a team that will set off together, on an exploratory mission to a distant planet. Selected humans might be able to live there in the future. What questions would they like to ask the captain before committing?

Information gathering roles: If the children have information they have acquired and can pass on within a drama, then the teacher can give themselves the role of someone who wants to know that information. For example, if the children are archaeologists in Egypt with Howard Carter, waiting for Lord Caernarvon to arrive before opening the tomb (Tutankhamun's), then they might talk secretly to the press (teacher in role), telling them what they know at this point. This enables the teacher to assess their current knowledge and understanding by asking the children questions and getting them to elaborate. Or maybe the teacher is a visitor to a village with a resident dragon. The visitor would have plenty of questions to ask and the children would answer them creatively together, building their storydrama collectively.

Very few roles will fall completely into one category. When you are giving information in role, you are likely to also be gathering information too, intentionally or otherwise.

\section{6) How long do you stay in role for?}

You only stay in role, for as long as it necessary for the purposes of the children's learning and the drama itself. Once the role has fulfilled its function and purpose, you come out of role. You can return in role if and when necessary. You can also take a different role at another point in the drama, if there is a purpose in doing so, e.g. returning as someone different, who was not present in an earlier scene and asking the children to tell you in role, what happened. This can be a way of giving them practice at recounting events, checking that they all agree and understand what has happened in the drama, before moving on. 


\section{Yaratıcı Drama Dergisine İlişkin Açıklamalar ve Yazım Kuralları}

\section{Yaratıcı Drama Dergisi’ne Yayımlanmak üzere gönderilen yazılar:}

1. İlk olarak iThenticate ya da Turnitin gibi intihal programları ile taranır ve alıntı oranı \% 15 altında olan çalışmalar alana uygunluk açısından öncelikle editör tarafından incelenerek yayın kuruluna iletilir. Yayımlanmasına karar verilen yazılar, bilimsel açıdan değerlendirilmek üzere en az iki hakem tarafindan incelenir.

2. Hakem raporlarından birinin olumlu, diğerinin olumsuz olması durumunda, makale değerlendirilmek üzere üçüncü hakeme yönlendirilir. Hakem raporlarının olumlu olması durumunda yazı, yayım programına alınır.

3. Hakem raporlarına göre üzerinde değişiklik yapılması gereken yazılardaki tüm değişiklikleri yazarlar kendileri yaparlar. Son şekli verilen yazılar üzerinde yazarlarca bir değişiklik yapılmaz.

4. Hakem raporları gizlilik içerir. Yazarlar, hakem ve Yayın Kurulu'nun eleştiri, öneri ve düzeltmelerini dikkate almak zorundadırlar. Yazarlarla hakemler arasındaki iletişimi yalnızca Yayın Kurulu sağlar.

5. Yayım sırasında, ilk olarak yazının Yaratıcı Drama Dergisi'ne gönderiliş tarihi, sonra da hakemlerden alınan puanlar dikkate alınmaktadır.

6. Yaratıcı Drama Dergisi'nde yayımlanan yazıların sorumluluğu yazar/lar/a aittir. Yayımlanan yazılar konusunda Çağdaş Drama Derneği ve Yaratıcı Drama Dergisi sorumluluk kabul etmez.

7. Yayın Kurulu, gönderilen yazıları yayımlayıp yayımlamamakta serbesttir. Gönderilen yazılar yayımlansın veya yayımlanmasın yazara iade edilmez.

8. Yayımlanmış yazıların yayın hakları Yaratıcı Drama Dergisi’ne aittir.

9. Yaratıcı Drama Dergisi’nin ve yazar/ların adları kaynak gösterilerek alıntı yapılabilir.

10. Yazılar, yazar soyadına göre alfabetik sırada yayımlanır. İki ya da daha fazla yazarlı makalelerde yazılar, ilk yazarın soyadı esas alınarak sıralanıp yayımlanır.

11. Bir sayıda, aynı yazarın tek isim olduğu tek makale yayımlanabilir.

12. Dergiye gönderilecek yazılar;

a) Kağıt boyutları: A4 boyutunda kağıda, üst, alt, sağ ve soldan $2,5 \mathrm{~cm}$ boşluk bırakılarak (16x24,7 cm'lik alana), 1,5 satır aralıklı, 11 punto ve Times New Roman yazı karakteri kullanılarak yazılmalıdır.

b) Tablo, resim, şekil, grafik vb.: Derginin sayfa boyutlarının dışına taşmaması amacıyla 10x17 cm'lik alanı aşmamalıdır. Tablo, resim, şekil, grafik ve benzerlerinde daha küçük punto ve bir satır aralığı kullanılabilir. Tablo, şekil ve ekler, metin içerisinde, başlıklarıyla yer almalıdır. Tablo ve şekillerin öncesine ve sonrasına $12 \mathrm{nk}$ boşluk verilir, tablo başlıkları ve metin 10 punto, tablo ve numarası koyu yazılmalıdır.

c) Makale Başlığı; 14 punto, bağlaçlar hariç her sözcügün baş harfi büyük olarak yazılmalıdır. Başlık 17 sözcüŭü geçmemelidir. Proje kapsamında hazırlanan, sözlü bildiri, doktora ya da yüksek lisans tezinden üretilmiş veya destek almış çalışmalar başlığa * şeklinde dipnot ile verilir. Başlıktan sonra bir boşluk ile dipnot verilmelidir. 
d) Yazar Ad/lar/ı; 12 punto, ortalı, yazar adı soyadı sadece baş harfleri büyük olarak dipnotta rakamla $1-2$ şeklinde verilmelidir.

e) Özet Başı̆̆ğ; 10 punto ve koyu yazılmalıdır.

f) Türkçe/İngilizce Özet Metni; 10 punto, iki tarafa yaslı şekilde, 150-250 sözcük arası yazılmalıdır. Paragraf var ise paragraflar arası $6 \mathrm{nk}$ boşluk verilmelidir.

g) Anahtar Sözcükler Başıı̆̆ı; 10 punto, koyu yazılmalıdır.

h) Anahtar Sözcükkler; 10 punto büyüklüğünde, en fazla 5 anahtar sözcük yazılmalıdır.

i) Ana Başlıklar; (Giriş, Yöntem, Tartışma ve benzeri temel başlıklar)10 punto, koyu ve ortalı, altından ve üstünden $6 \mathrm{nk}$ boşluk ile yazılmalıdır.

j) Alt Başlıklar; paragraf başı 1,25 $\mathrm{cm}$ içerden, 11 punto, koyu, italik, iki yana yaslı yazilmalidir.

k) Paragraflar; paragraf başları 1,25 cm içeriden, 11 punto, iki yana yaslı, paragraflar arası $6 \mathrm{nk}$ boşluk bırakılarak yazılmalıdır.

13. Gönderilen yazılar; özetler ve kaynakça dahil 20 sayfayı geçmemelidir.

14. Gönderilen yazılar aşağıdaki bölümleri içermelidir:

a) Başık sayfası: Yazar/lar/ın tüm ve açık adları, çalıştıkları kurumlar, makale üst başlığının Türkçe ve İngilizce isimleri ile Türkçe ve İngilizce özetleri içermelidir.

b) Ana Metin: Ampirik çalışmalar; giriş, yöntem, bulgular, tartışma ve sonuç bölümlerini içermelidir.

c) Yöntem: Bu kısım; örneklem, veri toplama aracı ve işlem, verilerin analizi alt k1sımlarını içermek zorundadır. Derleme türü çalışmalar problemi ortaya koymalı, ilgili alanyazını etkili bir biçimde analiz etmeli, alanyazındaki eksiklikler, boşluklar ve çelişkilerin üzerinde durmalı ve çözümler için öneriler içermelidir. Diğer çalışmaların başlıklandırılmasında farklılıklar olabilir, ancak yazıların okuyucuyu sıkmayacak akıcılık ve bilimsellikte olması gerekmektedir.

d) Kaynakça: Hem metin içinde hem de kaynakçada Amerikan Psikologlar Birliği (APA) tarafindan yayınlanan Puplication Manual of American Psychological Association (5. Bask1 2001) adlı kitapta belirtilen yazım kurallarına uyulmalıdır.

15. Yayın Kurulu ile ilgili yazışmalar için e-posta adresi mutlaka yazılmalıdır.

16. Türkçe makalelerde metin içinde referans verirken mümkün olduğu kadar ana kaynağa ulaşılmalıdır.

17. Yazılar, Yaratıcı Drama Dergisi’nin e-posta adresine (cdddergi@gmail.com) gönderilmelidir.

18. Yayımlanan yazıların içeriğinde olabilecek çarpıtmalardan, alıntı yapan yazar ya da yazarlar sorumludur.

19. Yaratıcı Drama Eğitmenlik/Liderlik kurslarında bitirme projesi olarak yapılan çalışmalar danışman adı ikinci isim olmak üzere, danışman adıyla birlikte yayımlanır.

20. Başka bir yerde yayımlanan yazılar (yayımlanmış seminer ve kongre bildirileri, vb.), Yayın Kurulu'nun onayıla Yaratıcı Drama Dergisi'nde yayımlanabilir. 


\section{Yaratıcı Drama Dergisi Kaynakça Yazım Örnekleri}

Dergimizde Amerikan Psikologlar Derneği (Publication of Manual of American Psychological Association-APA) tarafından yayınlanan yazım ilkeleri benimsenmiştir.

\section{Kitap}

Adıgüzel, Ö. (2013). Eğitimde yaratıcı drama (4.bs.). Ankara: PegemA Yayınları.

Gönderme: (Adıgüzel, 2013, s.234)

\section{İki Yazarlı Kitap}

Kitson, N. ve Spiby, I. (1997). Drama 7-11: Developing primary teaching skills (3rd ed.). New York:

Routledge Publication.

\section{Kitap İçinde Bölüm}

Güven, İ. (2008). Okul öncesi drama etkinliklerinde ilkeler. A. Öztürk (Yay. Haz.). Çocukta Yaratıcılık ve Drama içinde (ss. 199-212). Eskişehir: Anadolu Üniversitesi Yayınları.

Gönderme: (Güven, 2008, s.207)

\section{Çeviri Kitap}

Lewis, B. (2000). Modern Türkiye'nin doğuşu (M. Kıratlı, Çev.). Ankara: Türk Tarih Kurumu. Gönderme: (Lewis, 2000, s. 12)

\section{Editörlü Kitap}

Kilpatrick, J. (2004). (Ed.). A Research companion to principles and xtandards for school mathematics,

Reston, VA: NCTM, Inc. Educational Research Information Center (ERIC)

\section{Tek Yazarlı Makale}

San, İ. (1990). Eğitimde yaratıcı drama. Ankara Üniversitesi Eğitim Bilimleri Fakültesi Dergisi, 23(2), 573-582.

Gönderme: (San, 1990, s. 574)

\section{İki yazarlı makale}

Özdemir, P. ve Akkuş-Çıkla, O. (2005). Use of creative drama in science and mathematics by preservice elementary teachers. Hacettepe Üniversitesi Eğitim Fakültesi Dergisi, 27, 157-166.

\section{Elektronik Makale}

Karakelle, S. (2012). Üstbilişsel farkındalık, zeka, problem çözme algısı ve düşünme ihtiyacı arasındaki bağlantılar. Eğitim ve Bilim, 37(164), 237-250. 3 Aralık 2014 tarihinde http:// egitimvebilim.ted.org.tr/index.php/EB/article/view/779/376 adresinden erişildi.

Gönderme: (Karakelle, 2012, s. 240) 


\section{Tez}

Aykaç, M. (2011). Türkçe ögretiminde çocuk edebiyatı metinleriyle kurgulanan yaratıcı drama etkinliklerinin anlatma becerilerine etkisi. Yayınlanmamış doktora tezi, Ankara Üniversitesi Eğitim Bilimleri Enstitüsü Hacettepe, Ankara.

Gönderme: (Aykaç, 2011, s.67)

\section{Bildiri}

Akfirat Önalan, F. ve Tunç, A. (2003). Grup rehberlik etkinliklerinde yaratıcı dramanın yeri: Yaparak yaşayarak öğrenme. VII. Ulusal Psikolojik Danışma ve Rehberlik Kongresi 09-11 Temmuz 2003 içinde (s. 91-93). İnönü Üniversitesi, Malatya: PegemA Yayınc1lık, 139-140.

Gönderme: (Akfirat Önalan ve Tunç, 2003, s. 92)

\section{Web Sayfaları}

UNESCO. (2013). World Heritage list. UNESCO web sitesinden 21 Aralık 2013 tarihinde erişildi: http://whc.unesco.org/en/list

Gönderme: (UNESCO, 2013)

\section{Şekiller}

Her şeklin numarayı içeren bir başlığı olmalı ve bu başlık şeklin altına yazılmalıdır.

\section{Tablolar}

Tablo numarası ve adı tablonun üstünde yer almalıdır. Tablo adı, tablo numarasının altından başlayarak, sola dayalı bir şekilde, baş harfleri büyük ve italik olarak yazılmalıdır. Tablo sadece yatay çizgiler kullanılarak oluşturulmalıdır. Aşağıda bir tablo örneği verilmiştir.

Tablo 1. Yaratıcı Drama Temelli Hazırlanan Fen ve Matematik Ders Planlarının Sinıf Düzeyine ve Ünitelere Göre Dă̆ılımı

\begin{tabular}{cccccc}
\hline & 1. sınıf & 2. sınıf & 3. sınıf & 4. sinıf & 5. sınıf \\
\hline \multirow{2}{*}{ Yaşayan canlılar } & Fen ders planları & & & & \\
Elektrik & - & - & - & 5 & 1 \\
& - & - & 1 & 3 & - \\
Sayılar & Matematik ders planları & & & & \\
Geometri & - & - & 1 & - & 1 \\
Ölçme & 1 & - & 3 & 1 & 1 \\
Veri analizi & - & 2 & 1 & - & - \\
\hline
\end{tabular}




\section{Submission Guidelines for Creative Drama Journal}

\section{Articles sent to Creative Drama Journal for Publication:}

1. First, it is scanned with plagiarism programs such as iThenticate or Turnitin, and studies with a quotation rate of less than $15 \%$ are first reviewed by the editor and submitted to the editorial board. The articles, which are decided to be published, are examined by at least two referees to be evaluated from a scientific point.

2. In the event that one of the referee reports is positive and the other one is negative, article is directed to the third referee to be evaluated. In case of positive referee reports, article is included in the publication program.

3. Authors make all changes in the articles on which changes are required according to referee reports on their own. No change is made on the final versions of the articles by the authors.

4. Referee reports include privacy. Authors have to take the critics, suggestions and corrections of the referee and Editorial Board into consideration. Communication between authors and referees is only ensured by the Editorial Board.

5. During publication, firstly the sending date of the article to Creative Drama Journal is considered and then the scores obtained from the referees are considered.

6. Responsibility of the articles published in Creative Drama Journal pertains to the author/s/ of the articles. Contemporary Drama Association and Creative Drama Journal do not accept responsibility related to the published articles.

7. The Editorial Board is free to publish and not to publish the submitted articles. Submitted articles are not returned to the author whether they are published or not.

8. The rights of publication of the published articles pertain to Creative Drama Journal.

9. Quotation can be made by giving reference of Creative Drama Journal and the name/s of the author/s.

10. Articles are published in alphabetical order by authors' surnames. In articles with two or more authors, articles are sorted and published based on the first author's surname.

11. In an issue, one article can be published in which the same author is the only name.

12. Articles to be sent to the journal;

l) Paper sizes: It should be written on A4 sized paper with 1.5 line spacing and without end of line hyphenation by leaving $2,5 \mathrm{~cm}$ space from top, bottom and left (on an area of 16x24,7 cm) and by using 11 point size and Times New Roman typeface.

m) Tables, pictures, figures, graphics, etc..: They should not exceed the area of 10x17 $\mathrm{cm}$ in order not to extend beyond the journal page sizes. Smaller font size and one line space can be used on tables, pictures, figures, graphics and so on. Tables, figures and appendices should be included in the text with their titles. $12 \mathrm{pt}$ space is left before and after tables and figures, table titles and text should be 10 point size, table and its number should be written in bold.

n) Title of the Article; It should be written as 14 point size, and the first letter of every word should be written as capital letter except for the conjunctions. Title should not 
exceed 17 words. Studies, which are produced from verbal notification and doctoral or postgraduate thesis or which received support, are indicated by footnote in the title as *. Footnote should be given by a space after title.

o) Name/s of the Author/s; They should be given in footnote in figures as 1-2 along with the title, institution he/she works and e-mail address as 12 point size, centered, and only the first letters of author name and surname should be capital letter.

p) Title of Abstract; It should be written as 10 point size and in bold.

q) Turkish / English Text Abstract; It should be written as 10 point size, italic, justified alignment and between 90-120 words. If there is a paragraph, $6 \mathrm{pt}$ space should be given between paragraphs.

r) Title of the Keywords; It should be written as 10 point size and in bold.

s) Keywords; Maximum 5 keywords should be written as 10 point size.

t) Main Titles; (Introduction, Method, Discussion and similar basic titles) It should be written as 11 point size, bold and centered, in the way that only the first letters are capital letter, and with $6 \mathrm{pt}$ space from top and bottom.

u) Subtitles; paragraph indentation should be written as $1.25 \mathrm{~cm}$ inside, 11 point size, bold, italic and justified alignment.

v) Paragraphs; Paragraph indentations should be written as $1.25 \mathrm{~cm}$ inside, 11 point size, justified alignment by leaving $6 \mathrm{pt}$ space between paragraphs.

13. Submitted articles should not exceed 20 pages, including abstracts and references.

14. Submitted articles should include the following sections:

e) Title page: It should include the full name/s and explicit name/s of the author/s, the institutions they work, Turkish and English names of top article title and its Turkish and English abstracts.

f) Main Text: Empirical studies should include the sections of introduction, method, findings, discussion and the results.

g) Method: This section must include the sub-sections of sampling, data collection and processing and analysis of data. Review article-type studies should reveal the problem, should analyze the relevant literature effectively, should put emphasis on shortcomings, gaps and contradictions in the literature and should include suggestions for solutions. There may be differences in giving title of other studies, however, articles should be fluent and scientific that will not make the readers bored.

h) References: Spelling rules specified in the book called Publication Manual of American Psychological Association (5th edition 2001) published by American Psychological Association (APA) should be obeyed both in the text and references.

15. E-mail address must be written for correspondences related to the Editorial Board.

16. While giving reference in the texts in Turkish articles, main source should be attained as far as possible.

17. Articles should be sent to Creative Drama Journal's e-mail address (cdddergi@gmail.com). 
18. Author or authors who cite/s are responsible for the distortions that may be in the content of the published articles.

19. Studies carried out as dissertation in Creative Drama Instructor/Leadership courses are published with the name of advisor including the advisor name and second name.

20. The articles published in somewhere else (published seminar and conference proceedings, etc.) can be published in Creative Drama Journal with the approval of the Editorial Board.

\section{Citation Format and Style Guide for Creative Drama Journal}

Publication of Manual of American Psychological Association-APA is adopted by our journal for formatting and style.

\section{JOURNALS}

\section{One Author}

San, İ. (1998). The development of drama in education in Turkey, Research in Drama Education, 3, 1, 96.

\section{Two Authors}

Özdemir, P. ve Akkuş-Çıkla, O. (2005). Use of creative drama in science and mathematics by preservice elementary teachers. Hacettepe Üniversitesi Ĕ̆itim Fakültesi Dergisi, 27, 157-166.

\section{BOOKS AND CHAPTER IN BOOKS}

\section{One Author}

Üstündağ, T. (2004) Yaratıcı drama öğretmenimin günlüğü (6. bask1). Ankara: PegemA Yayınc1lık.

\section{Two Authors}

Kitson, N. ve Spiby, I. (1997). Drama 7-11: Developing primary teaching skills (3rd ed.). New York: Routledge Publication.

\section{Editor instead of author}

Hemingway, E. (1999). The killers. In J. Updike \& K. Kenison (Eds.), The best American short stories of the century (pp.78-80). Boston, MA: Houghton Mifflin.

Kilpatrick, J. (2004). (Ed.). A Research companion to principles and standards for school mathematics, Reston, VA: NCTM, Inc. Educational Research Information Center (ERIC)

\section{Thesis or dissertation}

Duatepe, A. (2004). The effects of drama based instruction on seventh grade students' geometry achievement, Van Hiele geometric thinking levels, attitude toward mathematics and geometry. Unpublished $\mathrm{PhD}$ dissertation, Ankara: METU. 


\section{Published Presentation Papers}

Adıgüzel, H. Ö. (2002). Eğitim bilimlerinde ve sanat eğitiminde yöntem, disiplin ve sanatsal boyutlarılla yaratıcı drama. 11. Eğitim Bilimleri Kongresi, Yakın Doğu Üniversitesi, KKTC, 23-26 Ekim.

\section{Online Sources}

\section{Online Journal}

Andersen, C. (2004, June). Learning in "As-If" worlds: Cognition in drama in education. . 43, 4, Retrieved November 3, 2004, Academic Index.

\section{Citing in the text}

\section{One Author}

Linn's (1999) study...

As it is indicated (Way, 1973) in a new research,...

\section{Two or more authors}

If the paper is published by two authors, then full names of both authors must be written through all the text. If the paper is published by three or more authors, then in the first citation full names of authors must be written, but then for other citations, only the first authors' first name must be written and other authors must be written as "others".

\section{Figures}

All the figures must have a title that include also a number. And this title must be under the figure.

\section{Tables}

The name and the number of table must be at the top of the table. Name of the table must begin after the number of table. And it must be aligned-left, written by initial capital letters and italic. The table must be constituted by only horizontal lines. You can find an example below.

Tablo 1. Yaratıcı Drama Temelli Hazırlanan Fen ve Matematik Ders Planlarının Sinıf Düzeyine ve Ünitelere Göre Dağılımı

\begin{tabular}{cccccc}
\hline & 1. sınıf & 2. sınıf & 3. sınıf & 4. sinıf & 5. sınıf \\
\hline \multirow{2}{*}{ Yaşayan canlılar } & Fen ders planları & & & & \\
Elektrik & - & - & - & 5 & 1 \\
& - & - & 1 & 3 & - \\
Sayılar & Matematik ders planları & & & & \\
Geometri & - & - & 1 & - & 1 \\
Ölçme & 1 & - & 3 & 1 & 1 \\
Veri analizi & - & 2 & 1 & - & - \\
\hline
\end{tabular}


